\title{
Effects of Microbial Transglutaminase for Gelation of Soy Protein Isolate during Cold Storage
}

\author{
Takahiko SOEDA \\ Ajinomoto Foundation For Dietary Culture, 1-16-7 Kyoubashi, Chuo-ku, Tokyo 104-8315, Japan
}

Received September 12, 2002; Accepted February 10, 2003

\begin{abstract}
On gelation of soy protein isolate during cold storage, strength, deformation, elasticity $E_{0}$ and Newtonian viscosity $\eta_{\mathrm{N}}$ of the gels greatly increased with addition of one unit/g protein of microbial transglutaminase when kept for 3 days at $5^{\circ} \mathrm{C}$, while retardation time $\lambda$ decreased. With addition of 3 units/g protein, the gels were too hard, but became brittle after being kept for 3 days at $5^{\circ} \mathrm{C}$. The viscoelasticity of gel treated during cold storage was superior to that of gel heated after having been kept in cold storage. It was assumed that the texture of the gel treated for one day at $5^{\circ} \mathrm{C}$ was nearly equivalent to that of the gel treated at $40^{\circ} \mathrm{C}$ for $60 \mathrm{~min}$, on enzyme reactivity of transglutaminase. $\varepsilon$ - $(\gamma$ glutamyl)lysine bonds in the gels were not formed in the case of the gel without transglutaminase, but increased linearly in the gel with transglutaminase. Contents of the sulfhydryl group of the gel were found to decrease during cold storage, and the degree of decrease was smaller in the gel with transglutaminase than in the gel without transglutaminase. This indicated less contribution of disulfide bonds in the gel treated with transglutaminase during cold storage.
\end{abstract}

Keywords: soy protein, gel formation, cold storage, microbial transglutaminase, $\varepsilon$-( $\gamma$-glutamyl)lysine bonds, sulfhydryl groups

Transglutaminase (glutaminyl-peptide: amine $\gamma$-glutamyltransferase, E.C. 2.3.2.13; TGase) catalyzes an acyl transfer reaction between a $\gamma$-carboxyamide of peptide or protein-bound glutamine and a primary amine.

When TGase acts on protein molecules, $\varepsilon$-( $\gamma$-glutamyl)lysine (abbreviated $\varepsilon-(\gamma$-Glu)Lys) bonds are formed. Many studies have been carried out to use this unique enzyme reaction, crosslinking between protein molecules, to change rheological properties of food proteins (Whitaker, 1977; Ikura et al., 1980; Motoki \& Nio, 1983). TGase, derived from a microorganism, has been found and mass produced (Ando et al., 1989). Enzymological properties and various basic effects on physical properties of food proteins have been reported (Soeda et al., 1992; Nonaka et al., 1992; Nonaka et al., 1994; Nonaka et al., 1996).

The principal mechanism of gelation of soy protein isolate (abbreviated SPI) is due to the formation of disulfide bonds, reported by Wolf and Smith (1961), Circle et al. (1964), Aoki and Sakurai (1969), Saio et al. (1971) on heat-induced gel, and by Watanabe et al. (1963), and Hashizume et al. (1974) on freezeinduced gel. On the other hand, as described in previous reports (Soeda, 1994a; 1994b; 1995a; Soeda \& Baba, 1999), the gel (abbreviated Cold-gel) was obtained by keeping it in cold storage. The Cold-gel showed physical properties characterized by flexibility and springiness, which were excellent compared with the viscoelasticity of heat-induced or freeze-induced gel. We also reported that characteristics of gels required for application of SPI gel in food processing were flexibility and springiness related to masticability and swallowing in the mouth, and that Cold-gel provided an improved texture in processed foods (Soeda, 1995b). These superior textural properties are thought to be ascribable to the mechanism of gelation. In our studies, it was

E-mail: takahiko_soeda_asb@ajinomoto.com suggested that Cold-gel resulted in formation of a network structure of protein based on hydrophobic and hydrogen bonds (Soeda, 1994b), whereas heat-induced and freeze-induced gel resulted in formation of a network structure between proteins composed mainly of disulfide bonds.

As described above, gel formation by microbial transglutaminase (abbreviated MTG) could be obtained without heating, the same as the gelation in Cold-gel. However, in past studies on physicochemical properties of MTG-treated gels of SPI, the gels were heated at $90^{\circ} \mathrm{C}$ for one hour to inactivate enzymes after treatment with MTG, and were not studied without heating. In the present studies, the effects of MTG on the gelation of SPI during cold storage were investigated without heating.

\section{Materials and Methods}

SPI SPI was prepared by the same methods as described in the previous report (Soeda, 1994a). Briefly, soy protein solution was prepared from undenatured defatted soybean flakes by solubilizing into water and coagulating by sulfuric acid. After adding water to the coagulant, soy protein solution with about $7 \%$ solid matter (about $5 \%$ protein) was heated at $100^{\circ} \mathrm{C}$ for 2 min by steam, and then freeze-dried. The composition of SPI obtained was $84.9 \%$ protein, $4.5 \%$ carbohydrate, $4.1 \%$ ash and $3.3 \%$ moisture.

Preparation of gel According to the method described in the previous report (Soeda, 1994a), SPI paste was adjusted to $19.5 \%$ protein concentration by adding water. After mixing, the paste was placed in a casing tube and kept for a maximum of 3 days at $5^{\circ} \mathrm{C}$ to prepare Cold-gel. Texture measurement of the control gel which had not been kept in cold storage was carried out directly after keeping it for one hour at $5^{\circ} \mathrm{C}$ in casing tubes filled with paste, to maintain a constant condition for measurement of the texture. 
The heat-induced gels (abbreviated Heat-gel) were obtained by heating at $90^{\circ} \mathrm{C}$ for 50 min directly after having been kept in cold storage. Further, gel treated at $40^{\circ} \mathrm{C}$ for $60 \mathrm{~min}$ (abbreviated $40^{\circ} \mathrm{C}$-gel) was prepared without cold storage treatment, for the purpose of investigating enzyme reactivity for protein of the substrate.

MTG MTG was prepared from the culture of a variant Streptoverticillium mobaraense as described (Ando et al., 1989). In all experiments the MTG product of 1.0 unit/mg of specific activity of enzyme was used. Enzyme activity was measured by the hydroxamate procedure with Carbobenzoxy-L-glutaminyglycine as the substrate (Folk \& Cole, 1996). Specific activity was defined as follows: one unit was the amount of the enzyme which catalyzed the formation of one $\mu \mathrm{mol}$ of hydroxamic acid/ $\min$ at $37^{\circ} \mathrm{C}$.

Determination of $\varepsilon-(\gamma-G l u)$ Lys bonds Analysis of $\varepsilon-(\gamma$ Glu)Lys bonds in the gel samples was performed as described by Kumazawa et al. (1993). Briefly, protein gel sample were lyophilized and an aliquot $(2 \mathrm{ml})$ of $0.1 \mathrm{M}$ sodium borate buffer $(\mathrm{pH}$ 8.0) was added to the lyophilized sample (equivalent $15-20 \mathrm{mg}$ protein). This mixture was incubated with a combination of pronase, leucine aminopeptidase, prolidase and carboxypeptidase A. The digested samples were then lyophilized and subjected to a two-step fractionation of $\varepsilon-(\gamma$-Glu)Lys with high performance liquid chromatography (HPLC). Elution time and $\varepsilon-(\gamma-\mathrm{Glu}) \mathrm{Lys}$ contents were estimated using a synthetic $\varepsilon$ - $(\gamma$-Glu $)$ Lys substance as a reference (Kumazawa et al., 1993). $\varepsilon$-( $\gamma$-Glu)Lys bonds reacted with $o$-phthalaldehyde (OPA) determined by measuring fluorescence.

The amount of $\varepsilon$ - $(\gamma$-Glu)Lys bonds was expressed in terms of $\mu \mathrm{mol}$ per $100 \mathrm{~g}$ of dry matter of the sample.

Determination of sulfhydryl groups Sulfhydryl groups were determined according to Ellman's DTNB method (Beveridge et al., 1974). Seventy-five mg of sample was suspended in $1 \mathrm{ml}$ of Tris-Gly(10.4 g Tris, $6.9 \mathrm{~g}$ glycine and $1.2 \mathrm{~g}$ EDTA per $l$, $\mathrm{pH}$ 8.0, denoted as Tris-Gly), $4.7 \mathrm{~g}$ of $\mathrm{GuHCl}$ was added, and the volume made up to $10 \mathrm{ml}$. For $\mathrm{SH}$, to $1 \mathrm{ml}$ of this solution was added $4 \mathrm{ml}$ of urea-GuHCl $(8 \mathrm{M}$ urea containing $5 \mathrm{M} \mathrm{GuHCl}$ in Tris-Gly) and then $0.05 \mathrm{ml}$ of Ellman's reagent ( $4 \mathrm{ml}$ of DTNB in $1 \mathrm{ml}$ of Tris-Gly) was added. For SS, to $1 \mathrm{ml}$ of the solution was added $0.05 \mathrm{ml}$ of 2-mercaptoethanol and $4 \mathrm{ml}$ of Urea$\mathrm{GuHCl}$, and the mixture was incubated for $1 \mathrm{~h}$ at $25^{\circ} \mathrm{C}$. After an additional $1 \mathrm{~h}$ incubation with $10 \mathrm{ml}$ of $12 \%$ TCA in Tris-Gly, the tube was centrifuged at $5000 \times \mathrm{g}$ for $10 \mathrm{~min}$. The precipitate was dissolved in $10 \mathrm{ml}$ of $8 \mathrm{M}$ urea in Tris-Gly and $0.04 \mathrm{ml}$ of Ellman's reagent was added. Absorbance was measured at 412 $\mathrm{nm}$ on a spectrophotometer.

Rupture test In accordance with the method described in the previous report (Soeda, 1994a), gel strength $\left(\mathrm{kg} \cdot \mathrm{m}^{-2}\right)$ and deformation (\%) were measured using a rheometer (Fudo Kogyo Inc., model NRM-2002 J).

Creep test Measurement of the creep test was carried out using a creep meter (YAMADEN Inc., model RE-3305) using the same method as described in the previous report (Soeda, $1995 a)$, and elasticity $E_{0}$, Newtonian viscosity $\eta_{\mathrm{N}}$ and retardation time $\lambda$ were calculated using a four factors kinetic model.

\section{Results and Discussion}

Behavior of rupture test on gels The effects of MTG on gelation of SPI during cold storage were studied by carrying out a rupture test. As shown in Fig. 1, the strength of Cold-gel without MTG gradually increased with prolongation of the period of cold storage. On the other hand, the strength of Cold-gel containing one unit/g protein of MTG greatly increased after one day of cold storage, and was constant after 3 days. The strength of Coldgel containing 3 units/g protein attained maximum after one day of cold storage, and decreased to the same level as Cold-gel containing one unit/g protein after 3 days. This decrease of gel strength might have been due to the brittleness of the gel which was induced by the excess formation of $\varepsilon-(\gamma-\mathrm{Glu})$ Lys bonds via MTG reaction during long periods of cold storage. When treated in cold storage for one day, strength of the gels containing one and 3 units/g protein of MTG was 3.5 times and 5.5 times, respectively for that of the Cold-gel without MTG.

The strength of Heat-gel heated for $50 \mathrm{~min}$ at $90^{\circ} \mathrm{C}$ after being kept in cold storage increased in the cases without MTG and with one unit/g protein when the period of cold storage was prolonged, especially in the latter case. The Heat-gels containing 3 units/g protein did not show a big change of gel strength after being kept in cold storage.

The deformation of Cold-gel without MTG increased with prolongation of the period of cold storage. In the case of gels with MTG, the deformation of Cold-gels containing one unit/g protein increased after one day of cold storage, and decreased after 3 days. Deformation of Cold-gels containing 3 units/g protein decreased with prolongation of the period of cold storage, especially after 3 days. The deformation of the Heat-gels increased in a case without MTG and with one unit/g protein, and decreased in a case with 3 units/g protein and prolongation of the period of cold storage.

In Fig. 1, the reason that gel strength and deformation of H-gel with MTG were lower than C-gel with MTG added with units/g protein could be attributed to the more brittle characteristics of the former gel based on the excess formation of $\varepsilon-(\gamma$-Glu $)$ Lys bonds by heat.

Behavior of creep test on gels Regarding the creep test, as shown in Fig. 2, elasticity $E_{0}$, and Newtonian viscosity $\eta_{\mathrm{N}}$ of the Cold-gels without MTG slightly increased as the period of cold storage was prolonged, while retardation time $\lambda$ decreased.

When MTG was added to gels, elasticity $E_{0}$, and Newtonian viscosity $\eta_{\mathrm{N}}$ increased linearly in proportion to the increasing
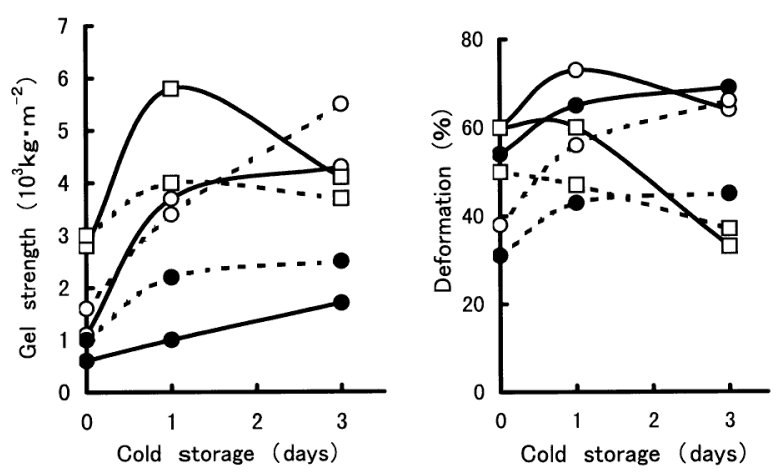

Fig. 1. Changes of texture on rupture test in gels prepared from soy protein isolate during cold storage. 0 : MTG 0 unit/g protein, $\bigcirc$ : MTG 1 unit/g protein, $\square$ : MTG 3 units/g protein. —: Cold-gel, -----: Heat-gel. 
dose of MTG, with prolonged periods of cold storage. The retardation time $\lambda$ of Cold-gels containing one and 3 units/g protein of MTG decreased as did Cold-gels with no MTG. On the other hand, on creep behavior of Heat-gels, elasticity $E_{0}$ and Newtonian viscosity $\eta_{\mathrm{N}}$ of the gels without and with MTG increased, and the retardation time $\lambda$ decreased with a prolonged period of cold storage.

Optimum temperature of MTG is about $40-50^{\circ} \mathrm{C}$. Thus, the creep test of the $40^{\circ} \mathrm{C}$-gel was carried out by adding one and 3 units/g protein of MTG. The results are given in Fig. 3. In this figure, $40^{\circ} \mathrm{C}$-gels were compared with Cold-gels kept at $5^{\circ} \mathrm{C}$ for one and 3 days. The creep parameters of the $40^{\circ} \mathrm{C}$-gel showed the same behavior as those of Cold-gel with one unit/g protein of MTG during cold storage, and were lower than those of Cold-gel added with 3 units/g protein. It was suggested that treatment for minutes at $40^{\circ} \mathrm{C}$ was equivalent to that for one day of cold stor-
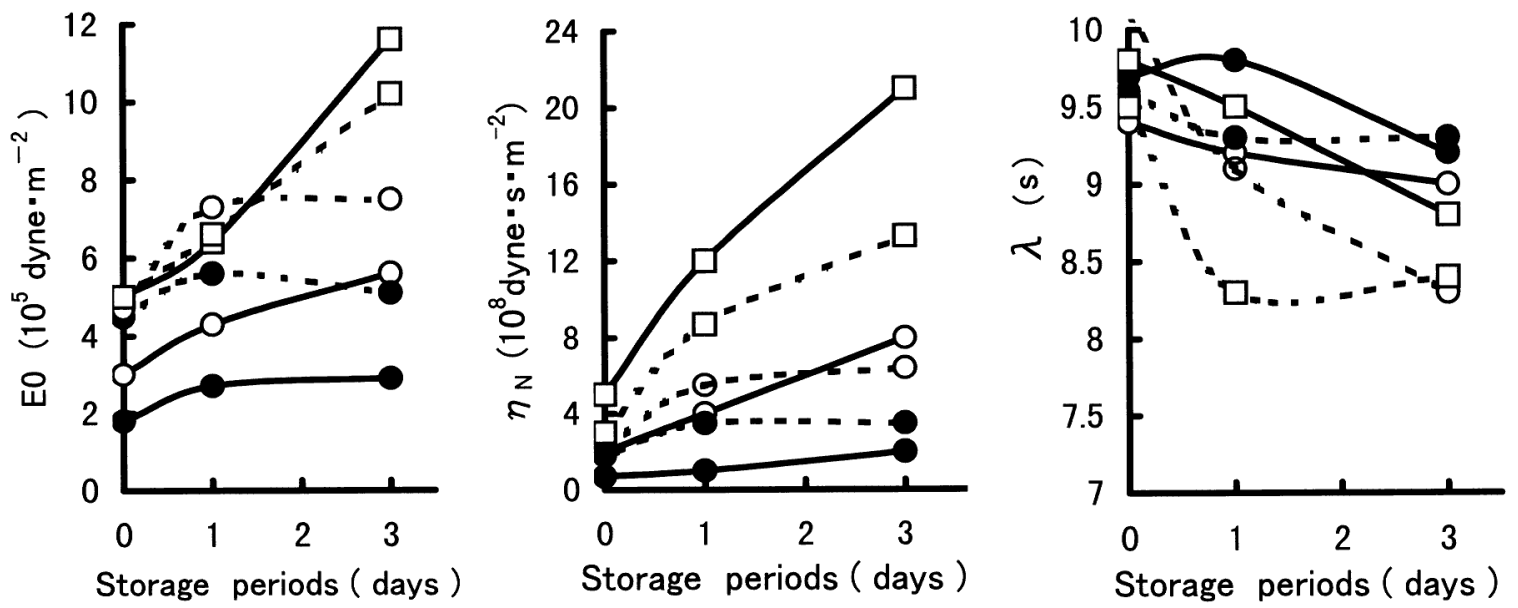

Fig. 2. Changes of texture on creep test in gels prepared from soy protein isolate during cold storage. $\bullet$ : MTG 0 unit/g protein, $\bigcirc$ : MTG 1 unit/g protein, $\square$ : MTG 3 units/g protein. —: Cold-gel, ------: Heat-gel.
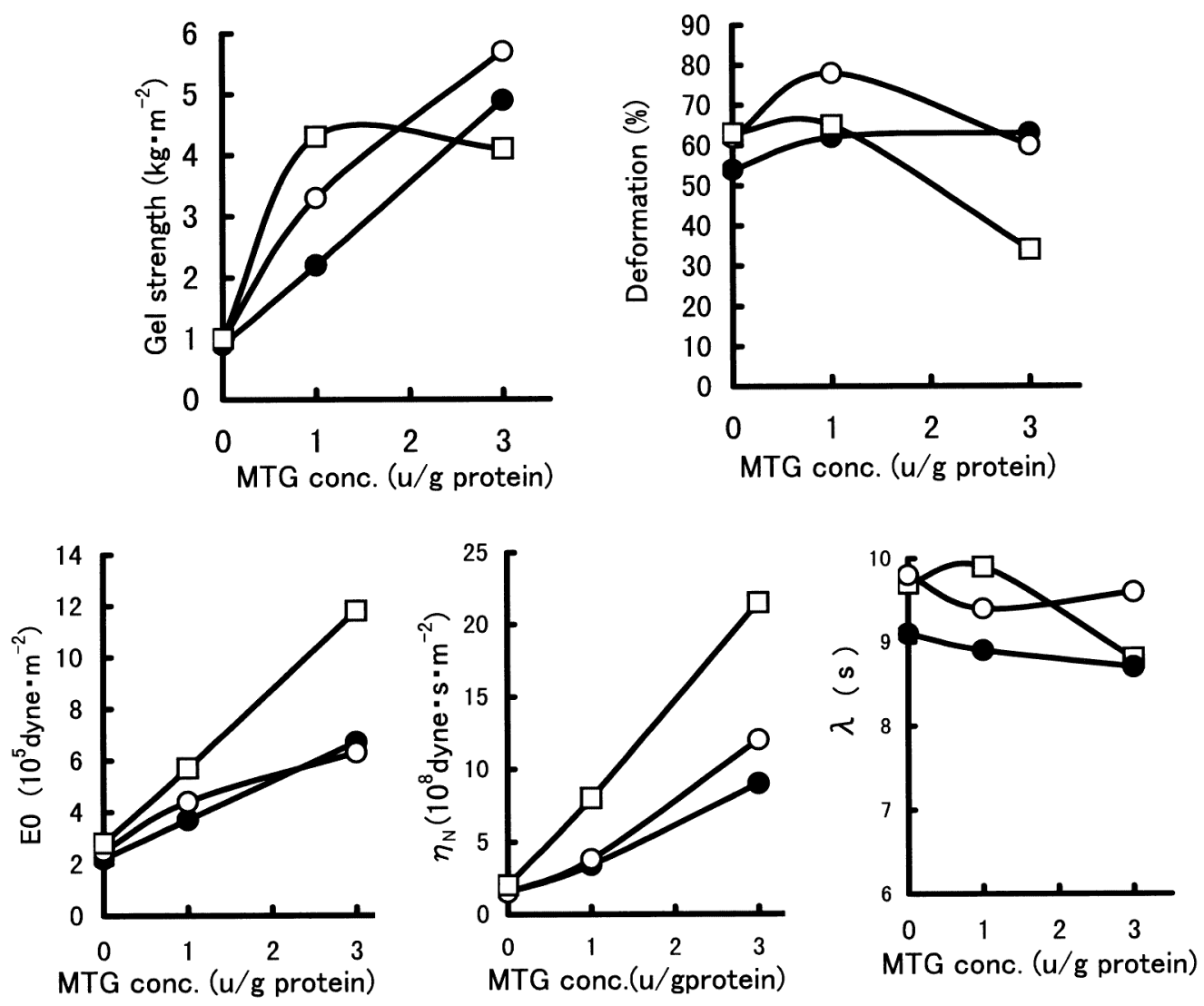

Fig. 3. Relationships of texture between $40^{\circ} \mathrm{C}$-gel and Cold-gel prepared from soy protein isolate. at $5^{\circ} \mathrm{C}$ for one day, $\square$ : Cold-gel treated at $5^{\circ} \mathrm{C}$ for 3 days. 


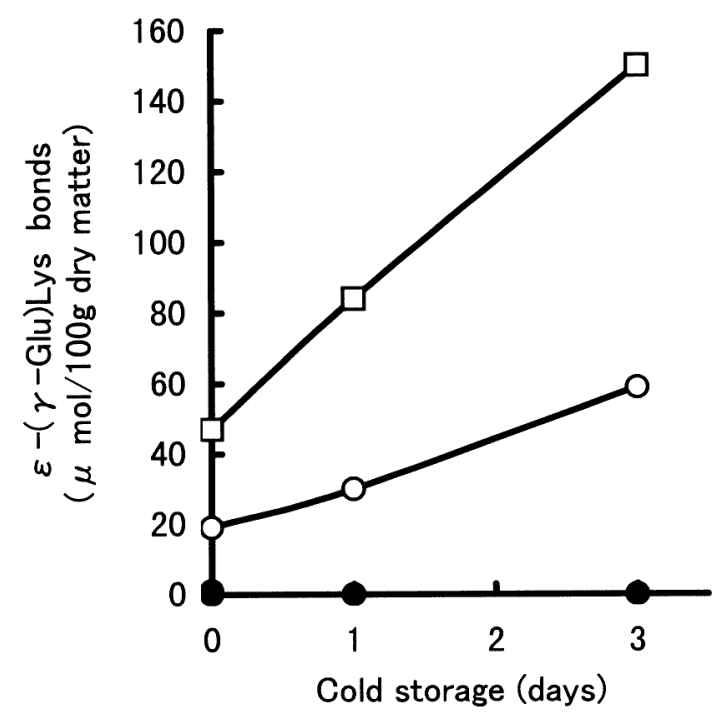

Fig. 4. Changes of $\varepsilon-(\gamma-\mathrm{Glu}) \mathrm{Lys}$ bonds on gels stored at $5^{\circ} \mathrm{C}$. $\bullet$ : MTG 0 unit/g protein, $\bigcirc$ : MTG 1 unit/g protein, $\square$ : MTG 3 units/g protein.

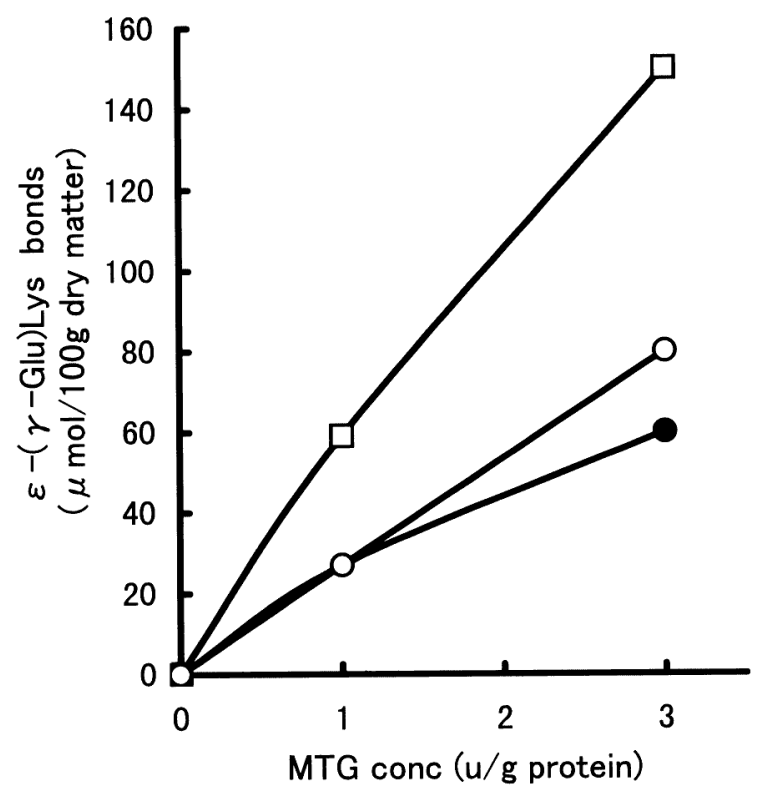

Fig. 5. Changes of $\varepsilon$ - $(\gamma$-Glu $)$ Lys bonds in gels stored at $5^{\circ} \mathrm{C}$. $40^{\circ} \mathrm{C}$-gel treated at $40^{\circ} \mathrm{C}$ for $60 \mathrm{~min}, \bigcirc$ : Cold-gel treated at $5^{\circ} \mathrm{C}$ for one day, $\square$ : Coldgel treated at $5^{\circ} \mathrm{C}$ for 3 days.

age at $5^{\circ} \mathrm{C}$, on enzyme reactivity for protein substrate.

On the sensory profile, the physicochemical properties of the Cold-gels with MTG during cold storage tended to increase in hardness and tightness. It was understood that the gels hardened due to an increase in elasticity $E_{0}$ and Newtonian viscosity $\eta_{N}$, and became brittle due to the decrease in retardation time $\lambda$. As described in previous reports (Soeda et al., 1992; Nonaka et al., 1994), the changes in physicochemical properties of the gel are assumed to be due the formation of a network structure between protein molecules as a result of cross-linking of polymerization between glutamine and lysine by the action of MTG.

Content changes of $\varepsilon-(\gamma-G l u)$ Lys bonds in gels As shown in Fig. 4, $\varepsilon$ - $(\gamma$-Glu)Lys bonds were not formed in the gel with no

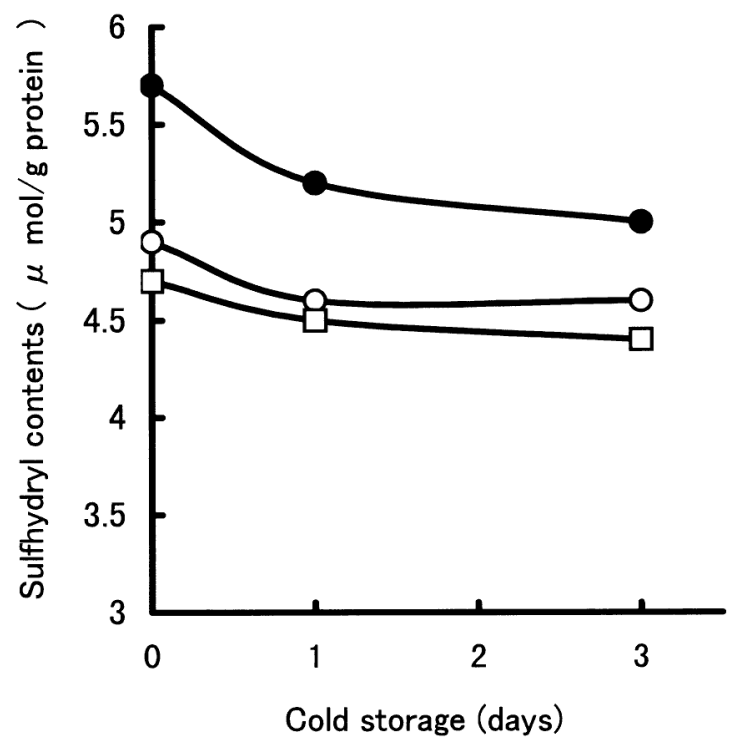

Fig. 6. Changes of sulfhydryl contents in gels stored at $5^{\circ} \mathrm{C}$. $\bullet$ : MTG 0 unit/g protein, $\bigcirc$ : MTG 1 unit/g protein, $\square$ : MTG 3 units/g protein.

MTG. In contrast, when MTG was added to the gel system, $\varepsilon-(\gamma-$ Glu)Lys bonds linearly formed according to prolongation of the period of cold storage and in proportion to the dose of MTG. Comparision of Fig. 4 with Fig. 2 shows that the contents of $\varepsilon$ $(\gamma$-Glu)Lys bonds formed are in good agreement with the values of elasticity $E_{0}$ and Newtonian viscosity $\eta_{\mathrm{N}}$ obtained by the creep test.

For the purpose of investigating the enzyme reactivity of MTG, the contents of $\varepsilon$ - $(\gamma$-Glu)Lys bonds were measured using gels treated for $60 \mathrm{~min}$ at $40^{\circ} \mathrm{C}$ which was the optimum temperature of MTG. As shown in Fig. 5, the contents of $\varepsilon-(\gamma$-Glu)Lys bonds in the gels obtained by treatment at $40^{\circ} \mathrm{C}$ for $60 \mathrm{~min}$ showed $31.4 \mu \mathrm{mol}$ with the addition of one unit/g protein, and $57.4 \mu \mathrm{mol}$ with the addition of 3 units/g protein of MTG. On the other hand, the contents of $\varepsilon$ - $(\gamma$-Glu)Lys bonds in the gels kept in cold storage for one day at $5^{\circ} \mathrm{C}$ were $25.2 \mu \mathrm{mol}$ in one unit/g protein of MTG, and $78.0 \mu \mathrm{mol}$ in 3 units/g protein. Consequently, the enzyme reactivity of MTG for one day at $5^{\circ} \mathrm{C}$ was nearly equal to that in $40^{\circ} \mathrm{C}$ for $60 \mathrm{~min}$.

Content changes of sulfhydryl groups in gels As described in the previous report (Soeda, 1995a), the decrease in contents of sulfhydryl groups in Cold-gel during cold storage was understood to be due to the formation of disulfide bonds between protein molecules. Thus, the contents of sulfhydryl groups in gels obtained with and without MTG were determined during cold storage. As shown in Fig. 6, contents of these groups were recognized to decrease during cold storage, however, the degree of decrease was smaller in gels with MTG than in those without MTG. It was suggested that MTG had less contribution to the formation of a network structure between protein molecules by disulfide bonds.

\section{Conclusions}

The effects of MTG on gelation of SPI during cold storage were studied. Gelation during cold storage was markedly promoted by the addition of MTG. Gel strength, deformation, elas- 
ticity $E_{0}$, and Newtonian viscosity $\eta_{\mathrm{N}}$ of Cold-gels clearly increased by adding MTG during cold storage, while retardation time $\lambda$ decreased. However, after 3 days of cold storage, the strength of gels containing 3 units/g protein of MTG was lower than that of gel containing one unit/g protein, and decrease in the deformation was also greater. Addition of MTG caused an increase in hardness and toughness in the mouth, as evidenced by the increased gel strength, elasticity $E_{0}$ and Newtonian viscosity $\eta_{\mathrm{N}}$, and the decreased retardation time $\lambda$.

The Cold-gels with MTG were markedly greater in gel strength, elasticity $E_{0}$ and Newtonian viscosity $\eta_{\mathrm{N}}$ than H-gels heated after cold storage. It was suggested that gel characteristics were changed to be more rigid but brittle by the excess formation of cross-linkage between protein molecules by heat, in the case of a large dosage of MTG and/or long periods of cold storage. In the gels containing MTG, the contents of $\varepsilon$ - $(\gamma$-Glu)Lys bonds linearly increased according to prolongation of the period of cold storage. When the dose of MTG was increased, the contents of $\varepsilon$ $(\gamma$-Glu)Lys bonds that had formed also increased.

With regard to physicochemical properties of the gel, the changes of elasticity $E_{0}$ and Newtonian viscosity $\eta_{\mathrm{N}}$ of Cold-gels as observed in the creep test were in good agreement with changes of the contents of $\varepsilon-(\gamma$-Glu)Lys bonds formed. The contents of sulfhydryl groups in the gels were found to decrease during cold storage, and the degree of decrease was smaller in the gels treated with MTG than in those treated with no MTG. This indicated less contribution of disulfide bonds in the gels treated with MTG during cold storage.

\section{References}

Ando, H., Adachi, M., Umeda, K., Matuura, A., Nonaka, M., Uchio, R., Tanaka, H. and Motoki, M. (1989). Purification and characteristics of a novel transglutaminase derived from microorganisms. Agric. Biol. Chem., 53, 2613-2617.

Aoki, H. and Sakurai, M. (1969). Studies on the gelation of soybean protein. On the effects of heat denaturation. Nippon Nogei Kagaku Kaishi, 43, 448-456 (in Japanese).

Beveridge, T., Toma, S.J. and Nakai, S. (1974). Determination of SHand SS-groups in the same food proteins using Ellman's reagent. $J$. Food Sci., 39, 49-51.

Circle, S.J., Meyer, E.W. and Whtner, R.W. (1964). Rheology of soy protein dispersion. Effect of heat and other factors on gelation. Cereal Chem., 41, 157-172.

Folk, J.E. and Cole, P.W. (1996). Mechanism of action of guinea pig liver transglutaminase. J. Biol. Chem., 241, 5518-5525.

Hashizume, K., Nakayama, N. and Watanabe, T. (1974). Studies on the changes of the properties of soybean protein by freezing. Improved production of new textured protein by freezing. Nippon Shokuhin kougyo Kagaku Kaishi, 21, 141-145 (in Japanese).

Ikura, K., Kometani, T., Yoshikawa, M., Sasaki, R. and Chiba, H. (1980). Crosslinking of casein components by transglutaminase. Agric. Biol. Chem., 44, 1567-1573.

Kumazawa, Y., Seguro, K., Takamura, M. and Motoki, M. (1993). Formation of $\varepsilon$ - $(\gamma$-glutamy $) L y$ sine cross-link in cured horse mackerel meat induced by drying. J. Food Sci., 58, 1062-1064, 1083.

Motoki, M. and Nio, N. (1983). Crosslinking between different food proteins by transglutaminase. J. Food Sci., 48, 561-566.

Nonaka, M., Sakamoto, H., Toiguchi, S., Kawajiri, H., Soeda, T. and Motoki, M. (1992). Sodium casinate and skim milk gels formed by incubation with microbial transglutaminase. J. Food Sci., 57, 12141218.

Nonaka, M., Toiguchi, S., Sakamoto, H., Kawajiri, H., Soeda, T. and Motoki, M. (1994). Changes caused by microbial transglutaminase on physical properties of thermally induced soy protein gels. $J$. Hydrocolloides, $\mathbf{8}, 1-8$.

Nonaka, M., Sakamoto, H., Toiguchi, S., Yamagiwa, K., Soeda, T. and Motoki, M. (1996). Retort-resistant tofu prepared by incubation with microbial transglutaminase. J. Hydrocolloides, 10, 41-44.

Saio, K., Kajikawa, M. and Watanabe, T. (1971). Food processing characteristics of soybean protein. Effect of sulfhydryl groups physical properties of tofu-gel. Agric. Biol. Chem., 35, 890-898.

Soeda, T., Ishii, C., Yamazaki, K. and Murase, K. (1992). The effect of transglutaminase on texture of tofu. Nippon Shokuhin Kagaku Kogaku Kaishi, 42, 254-261 (in Japanese).

Soeda, T. (1994a). Gelation of soy protein isolate during cold storage. Nippon Shokuhin Kagaku Kogaku Kaishi, 41, 670-675 (in Japanese).

Soeda, T. (1994b). Effect of heating on the molecular structure of soy protein. Nippon Shokuhin Kagaku Kogaku Kaishi, 41, 676-681 (in Japanese).

Soeda, T. (1995a). Physical properties and microscopic observation of Cold-gel prepared from soy protein isolate. Nippon Shokuhin Kagaku Kogaku Kaishi, 42, 485-491 (in Japanese).

Soeda, T. (1995b). The function on food processing for the cold-gel prepared from heated soy protein isolate. Nippon Shokuhin Kagaku Kogaku Kaishi, 42, 672-676 (in Japanese).

Soeda, T. and Baba, K. (1999). The modification of soy protein on gel formation and its application for foods. Nippon Shokuhin Kagaku Kogaku Kaishi, 46, 627-632 (in Japanese).

Watanabe, T., Nakayama, O. and Iwasaki, N. (1963). Changes in water extract of soybean. Studies on the changes of the properties of soybean protein by freezing. Nippon Shokuhin Kagaku Kogaku Kaishi, 10, 163-166 (in Japanese).

Whitaker, J. (1977). In "Food Protein-Improvement through Chemical and Enzymatic Modification," American Chemical Society, ed. by R.E. Feeney and J.R. Whitaker, Washington, DC. pp. 95-155.

Wolf, W.J. and Smith, A.K. (1961). Food uses and properties of soybean protein. II. Physical and chemical properties of soybean protein. Food Tech., 15, 12-28. 